\title{
Modern-day Slavery at Sea: Human Trafficking in the Thai Fishing Industry
}

\author{
Zezen Z. Mutaqin ${ }^{* *}$
}

Most of the literature on modern-day slavery focuses on women and children as victims of the sex industry. This disproportionate emphasis on sexual exploitation has resulted in conflation of the term trafficking with prostitution, which has led to an understanding of human trafficking issues as separate from other workplace abuses that amount to slavery. By exploring modern-day slavery in the Southeast Asian fishing industry, this paper may fill a research gap within the study of human trafficking as well as sharpen our awareness of slavery practices, not only in the sex industry, but also in workplaces like fishing vessels and seafood processing factories. This paper will argue that the proximity of modern slavery to sexual exploitation and the lack of differentiation between smuggling and trafficking crime has led to the ignorance of contemporary slavery practices in other sectors.

\section{Keywords}

Human Trafficking, Slavery, Fishing Industry, Southeast Asia, Smuggling, Sex Trafficking

* The research and publication of this article is sponsored by Indonesia Endowment Fund for Education (LPDP Indonesia). The author would like also to thank Professor Khaled Abou El Fadl for his insightful comments.

** SJD candidate at UCLA Law School; Lecturer at Sharia and Law School Syarif Hidayatullah State Islamic University (UIN), Jakarta. LL.B. (UIN Jakarta), LL.M. (Melbourne). ORCID: https://orcid.org/0000-0002-5895-0813. The author may be contacted at: zezen.zaenal@uinjkt.ac.id / Address: Fakultas Syariah dan Hukum, UIN, Jl. H. Djuanda No. 59 Ciputat, Jakarta, Indonesia. 


\section{Introduction}

Modern-day slavery is omnipresent and connects directly to our lives, spanning from clothing and entertainments to the food industry. ${ }^{1}$ The 2015 US State Department's Trafficking in Persons (“TIP”) Report estimated that around 27 million men, women, and children have become victims of modern-day slavery in its various forms, including sex trafficking, debt bondage, forced labor, and child exploitation. ${ }^{2}$ If including other estimations, there are likely around 45 million people living in slavelike conditions, double the TIP's prediction. ${ }^{3}$ We may never know the actual number because the practice of modern-day slavery is hidden under the blanket of ignorance, concealed by a widespread assumption that it was eradicated from our society hundreds of years ago.

In modern times, slavery has been covered up under at least two different forms: labor contracts and prostitution. These practices have been transformed into a subtle form of oppression and servitude under different names. In the most extreme case, however, chattel slavery is still openly practiced and has become a backbone for the survival of many businesses such as mining, plantation and agriculture, construction, coal, and, notoriously, fishing industry.

Why does slavery still exist in the modern world? How could it be possible that 45 million people are living in slavery right now? In answering these questions, Kevin Bales, a leading specialist in this field, proposed three primary explanations: (1) the exponential growth of the world population, which provides "a glut of potential slaves"; (2) post-colonial modernity, which has created dramatic economic and social changes such as political conflicts, natural disasters, and economic inequality, causing a complex humanitarian crisis; and (3) corruption, especially among state officials like police and immigration officers. ${ }^{4}$

Utilizing Bales' framework, my research will engage in a forgotten story of modern-day slavery: the fishing industry in Southeast Asia, particularly in Thailand. Even though these practices have existed for decades, they are still relatively

1 As of 2012, there were around 139 goods from 75 countries produced by child and forced labor. See ThE US DEPT. of Labor, List of Goods Produced by Child Labor or Forced Labor (2016), available at https:/www.dol.gov/sites/ default/files/documents/ilab/reports/child-labor/findings/TVPRA_Report2016.pdf (last visited on Mar. 4, 2018).

2 TIP Report 2015, available at https://www.state.gov/documents/organization/245365.pdf (last visited on Mar. 5, 2018).

3 See Global Slavery Index, available at http://www.globalslaveryindex.org/findings (last visited on Mar. 5, 2018). Another organization like Polaris and ILO has different estimation by mentioning around 20 million victims of modernday slavery.

4 See, e.g., K. Bales, Ending Slavery 14-6 (2000). 
unknown. Only recently have they attracted the attention of some international organizations and media outlets. Abundant data and information have been published by international organizations, such as the International Organization for Migration ("IOM"), ${ }^{5}$ the UN, ${ }^{6}$ the International Labor Organization ("ILO"), Human Rights Watch, ${ }^{8}$ Greenpeace, ${ }^{9}$ and the Environmental Justice Foundation ("EJF"). ${ }^{10}$ This is, in addition to investigative media reports, published by The Associated Press ("AP"), ${ }^{11}$ Aljazeera, ${ }^{12}$ The Guardian, ${ }^{13}$ and BBC. ${ }^{14}$

However, academic publications still very rarely mention slavery in fishing industry. Kevin Bales' monumental book, Disposable People, ${ }^{15}$ for example, refers to the modern-day slavery in Thailand as the main case for his book, but he does not mention the phenomena of slavery in fishing industry at all. Nicola Piper's review on the research on trafficking in Southeast Asia and Oceania also fails to mention the slavery in seafood industry. ${ }^{16}$ Tom Obokata's book, TRAFFICKING OF HuMAN BeINGS

5 IOM, TRAFFicking of Fishermen IN Thailand (2011), available at https://www.iom.int/jahia/webdav/shared/shared/ mainsite/activities/countries/docs/thailand/Trafficking-of-Fishermen-Thailand.pdf(last visited on Apr. 17, 2018).

6 UNODC, Transnational Organized Crime in the Fishing Industry (2011), available at http://www.unodc.org/ documents/human-trafficking/Issue_Paper_-_TOC_in_the_Fishing_Industry.pdf(last visited on Apr. 17, 2018).

7 The following are the reports from ILO: The Mekong Challenge, Underpaid, Overworked and Overlooked: The realities of young migrant workers in Thailand (Vol. 1, 2006), available at http://www.ilo.org/asia/publications/WCMS BK_PB_67_EN/lang--en/index.htm; Caught at Sea--Forced Labor and Trafficking in Fisheries (2013), available at http://www.ilo.org/wcmsp5/groups/public/---ed_norm/---declaration/documents/publication/wcms_214472.pdf; and Employment Practices and Working Conditions in Thailand's Fishing Sector (2014), available at http://www.ilo.org/ dyn/migpractice/docs/184/Fishing.pdf (all last visited on Apr. 17, 2018).

8 Human Right Watch, From the Tiger to the Crocodile Abuse of Migrant Worker in Thailand (2010), available at https://www.hrw.org/sites/default/files/reports/thailand0210_insert_low.pdf (last visited Apr. 17, 2018).

9 Greenpeace, Supply Chained-Human Rights Abuses in the Global Tuna Industry (2015), available at http://www. greenpeace.org/usa/wp-content/uploads/2015/11/Supply-chained.pdf (last visited on Apr. 17, 2018).

10 The EJF published a series of report as follow: Sold to the Sea--Human Trafficking in Thailand's Fishing Industry (2013), available at http://un-act.org/publication/view/sold-sea-human-trafficking-thailands-fishing-industry; Slavery at Sea: The Continued Plight of Trafficked Migrants in Thailand's Fishing Industry (2014), available at https:// ejfoundation.org/resources/downloads/EJF_Slavery-at-Sea_report_2014_web-ok.pdf (all last visited on Apr. 17, 2018).

11 AP, Seafood from Slaves (2015-16), available at http://www.ap.org/explore/seafood-from-slaves (last visited on Mar. 4, 2018).

12 F. Lines, A trafficked fisherman's tale: 'My life was destroyed,' AlJAzEera, Mar. 5, 2016, available at http://www. aljazeera.com/indepth/features/2016/03/trafficked-fisherman-tale-life-destroyed-160303122451399.html (last visited on Mar. 5, 2018).

13 Staff reporter, Thailand accused of failing to stamp out murder and slavery in fishing industry, GuARDIAN, Mar. 30, 2017, available at https:/www.theguardian.com/global-development/2017/mar/30/thailand-failing-to-stamp-outmurder-slavery-fishing-industry-starvation-forced-labour-trafficking (last visited on Mar. 5, 2018).

14 See What Does Modern Slavery Look Like?, BBC, May 31, 2016, available at http://www.bbc.com/news/worldasia-36416751 (last visited on Mar. 5, 2018).

15 K. Bales, Disposable People: New Slavery in the Global Economy (2000).

16 N. Piper, A Problem by a Different Name? A Review of Research on Trafficking in South-East Asia and Oceania, 43 Int'L. Migration 203 (2005). 
from A Human Rights Perspective, compares human trafficking practices in Thailand, Poland, and the $\mathrm{UK}^{17}$ but it omits forced labor and slavery in fishing industry from this discussion. The Thai scholar Naparat Kranrattanasuit has written a more recent book, ASEAN AND HUMAN TRAFFICKING, ${ }^{18}$ in which Cambodia, Thailand and Vietnam are presented as case studies. This book mentions the problem of human trafficking in their fishing industry. Merely in passing, it primarily focuses on the role of the ASEAN combating modern-day slavery in general. Most researchers investigating modern-day slavery focus on sex trafficking and child exploitation. ${ }^{19}$ So far, Noami Jiyung Bang is possibly the only author who pays attention to the phenomenon of human trafficking in the fishing industry, in her proposal of a comprehensive initiative to reduce human trafficking in the global seafood chain. ${ }^{20}$

Most literature on modern-day slavery focuses on women and children as victims of the sex industry. This disproportionate emphasis on sexual exploitation has resulted in conflation of the term trafficking with prostitution and the sex industry. ${ }^{21}$ This amalgamated image has led to, as Jennifer Chacon has said, detaching human trafficking issues from other workplace abuses that amount to slavery. ${ }^{22}$ Thus, by elaborating the case of modern-day slavery in fishing industry, this paper may address such gap within the study of human trafficking, as well as heighten our awareness of slavery's presence not only in the sex industry but in other workplaces.

The author would argue that the conflation of modern slavery with sexual exploitation on the one hand, and the lack of clear differentiation between smuggling and trafficking crimes, on the other, has led to ignorance, especially among state officials and state enforcement agencies, that slavery also occurs in other sectors. In the context of Southeast Asia, a mix between migration, smuggling, and human trafficking has made the problem of combating slavery even more challenging. This paper is composed of four parts including Introduction and Conclusion. Part two will discuss fishing industry and slavery. Part three will reflect legal and conceptual

17 See generally T. Obokata, Trafficking of Human Beings from a Human Rights Perspective Toward a Holistic ApProach (2006).

18 N. Kranrattanasuit, ASEan and Human Trafficking Case Studies of Cambodia, Thailand, and Vietnam (2014).

19 For details on human (sex) trafficking in Thailand, see S. Molland, The Value of Bodies: Deception, Helping and Profiteering in Human Trafficking along the Thai-Lao Border, 34 Asian Stud. Rev. 221-9 (2010); N. Farrelly, Exploitation and Escape Journey across the Burma-Thailand Frontier, in LABOR Migration AND Human TRAFFicking IN Southeast Asia 131 (M. Ford et al. eds., 2012).

20 N. Jiyoung Bang, Casting a Wide Net to Catch the Big Fish: A Comprehensive Initiative to Reduce Human Trafficking in the Global Seafood Chain, 17 U. PA. J. L. \& Soc. Change 221 (2014).

21 H. Shamir, A Labor Paradigm in Human Trafficking, 60 UCLA L. REv. 88 (2012-13). [Emphasis added]

22 J. Chacon, Misery and Myopia: Understanding the Failure of the U.S Effort to Stop Human Trafficking, 74 FordHAM L. REV. 2977 (2006). 
question in this regard.

The term "modern-day slavery" will be used interchangeably in this paper with 'human trafficking' or "trafficking in persons." Although the formal, legal definition used in international conventions and many domestic legislations is "trafficking in persons," 'human trafficking' has been used widely by academic and popular publications to refer to contemporary slavery practices.

\section{Fishing Industry and Slavery}

\section{A. Why Do We Care?}

Sex trafficking may connect to you directly only if you are a 'john' or a consumer of pornographic-related entertainment. However, labor slavery links to many aspects of daily life even if you have pets, consume foods such as chocolate and seafood, drink coffee or tea, or own particular clothing brands or electronics. ${ }^{23}$ The global economy necessitates that capital move to places where the cost of production can be reduced to a very low point. Sophisticated chains of production mean that many companies are unaware or unwilling to acknowledge that, for example, the tin used in most electronic products is shipped from the Indonesian island of Bangka, where massive child exploitation occurs. ${ }^{24}$ We never know that shrimp and other seafood or canned pet food at the nearby supermarket are products of slavery and horrible human suffering in Southeast Asia. ${ }^{25}$

Although human trafficking exists in many different industries of Southeast Asian countries, this paper will focus mainly on Thailand's fishing sector. Despite the fact that many studies have been conducted on slavery in Southeast Asia in general, Thai human trafficking in fishing industry has been neglected. However, by focusing on fishing industry, in particular on fishing vessels in Thailand, my paper actually covers briefly almost the whole region of Southeast Asia, not just Thailand. The classic traffic

23 For a complete list of products regarding forced labor and exploitation, see Anti-Slavery International, Product of Slavery and Child Labor, available at http://www.antislavery.org/wp-content/uploads/2016/11/products_of_slavery_ and child labour_2016.pdf (last visited on Mar. 4, 2018). See also THE US DEPT. OF LABOR, supra note 1.

24 Indonesia is the second largest tin exporter. For details, see K. Hodal, Death Metal: Tin Mining in Indonesia, GuARDIAN, Nov. 23, 2012, available at https://www.theguardian.com/environment/2012/nov/23/tin-mining-indonesia-bangka; https:/www.theguardian.com/environment/2013/jul/12/apple-tin-mining-bangka-island-iphone (all last visited on Mar. 4, 2018).

25 AP, supra note 11. 
flow of 'source,' 'transit,' and 'destination' take place in different countries, including Cambodia, Myanmar, Laos, Thailand, Malaysia, and Indonesia. Concerning the trafficking in fishing industry, however, this flow may not be sufficiently clear-cut to fit with the classic pattern. ${ }^{26}$ Victims of slavery at sea might be recruited either in their country origin, such as Myanmar, Cambodia or Laos, at seaports across the region, or on the boats of registered flag states, where victims are transferred from one vessel to another while at sea. The victims are treated like a soccer ball, kicked in and out of harbors (transit) along territorial states, or transferred between the flag state vessels (destination) to catch fish at sea across Southeast Asia and beyond. ${ }^{27}$

This phenomenon has confused Southeast Asian leaders who should primarily have jurisdiction and responsibility in handling trafficking cases on these vessels. ${ }^{28}$ International law regulates that flag states have the right to exercise jurisdiction on the boats. However, it is actually difficult and costly to enforce the law to the longhaul fishing vessels afloat far away from the flag states. More worse, many boats are recently registered under "flags of convenience" ("FOC") ${ }^{29}$ like Panama, Belize, or the Cayman Islands to escape any criminal liability.

Thailand is the third biggest exporter of seafood products, with more than USD 7 billion in export value in 2011, reaching mostly the US (around USD 1.6 billion export values in 2013) and European markets (Euro 835.5 million). ${ }^{31}$ This means that, if you buy canned pet food or any seafood products from any store in the US or Europe, most of them would be coming from the Thai fishing industry. Unfortunately, the survival of this sector depends on an illicit collaboration of unscrupulous business owners, transnational trafficker networks, and corrupt government officials. ${ }^{32}$ Since 2010, several international organizations like the UNIAP Project, ILO, Human Rights Watch, EJF, and Greenpeace have published investigative reports about the Thai fishing industry, but these have circulated mainly among human rights activists and

UNODC, supra note 6 , at 42.

27 GREENPEACE, supra note 9.

28 UNODC, supra note 6 , at 42.

29 FOC is the term to identify individual flags state that becomes a safe haven for ship owners due to the fact that those countries have neither ability nor willingness to enforce the law or provide the mechanism to conceal the real beneficial owners of the ships. See A. Couper, Fishers and Plunderers Theft, Slavery and Violence at Sea 78-81 \& $95-98$ (2015).

30 UNODC, supra note 6, at 18-9. See also M. Giani \& W. Simon, The Changing Nature of High SEas Fishing (2005), available at $\mathrm{http}$ //assets.wwf.org.uk/downloads/flagsofconvenience.pdf (last visited on Apr. 8, 2018).

31 EFJ, The Continued Plight of Trafficked Migrants, supra note 14. See also FAO, The State of Fisheries and AQuACUlture 71 (2012); AP, supra note 11, at 16.

32 EJF, Slavery at Sea, supra note 10. 
never attracted wide attention. ${ }^{33}$

The Thai fishing industry relies partly on 200,000 foreign migrants working on fishing boats and another hundred thousand in the processing facilities onshore. ${ }^{34}$ The most egregious abuses of these workers occur on long-haul fishing vessels, on which victims are forced to work for weeks, months, even years at sea, for almost 24 hours a day in complete isolation and with no way to escape. Many of them, like those who are from Rakhine State (Rohingya), escape the agony of persecution in their place of origin, but are then re-trapped by traffickers and sold to the fishing boats as slaves. ${ }^{35}$ Refusal to work leads to beating and even torture on boats on the high sea. One victim testified that he saw 20 people died in front of him, one of whom was tied by his legs and hands to the bows of four boats that pulled him apart at sea. ${ }^{36}$ No one knew what happened on these boats for years, until a lengthy investigative report published by the AP in 2015 uncovered the brutal life conditions on these fishing vessels. ${ }^{37}$ Almost all international media featured the case of slavery in the Thai fishing industry in their headlines following the initial AP report.

This story had a significant impact. More than 2,000 slaves, mostly Burmese who worked for the Thai vessels, have been rescued and freed from several remote islands of eastern Indonesia. When freed, some of them were locked inside the Benjina Fishing Company compound for refusing to go back to work. ${ }^{38}$ Others have escaped from the boats and hid themselves inside the islands; they were isolated from the outside world for years. A dozen alleged traffickers were arrested both in Indonesia and Thailand. The Indonesian government immediately enforced a suspension and moratorium on foreign fishing vessels. Meanwhile, in the US, President Obama signed House Resolution 644, the Trade Facilitation and Trade Enforcement Act of 2015 , which bans the US import of goods allegedly produced by slavery. ${ }^{39}$

33 For details, see supra notes 5-10.

34 For details on alleged trafficking in the seafood processing plants, see ILO, The Mekong Challenge, supra note 7.

35 E. Stoakes et al., Sold from a Jungle Camp to Thailand's Fishing Industry: 'I Saw 13 People Die' GuARDIAN, July 20, 2015, available at $\mathrm{https}$ ://www.theguardian.com/global-development/2015/jul/20/sold-from-jungle-camp-thailandfishing-industry-trafficking (last visited on Mar. 4, 2018).

36 Id.

37 AP, supra note 11.

38 E. Htusan \& M. Mason, More than 2,000 enslaved fishermen rescued in 6 months, AP, Sept. 17, 2015, available at http://www.ap.org/explore/seafood-from-slaves/more-than-2,000-enslaved-fishermen-rescued-in-6-months.html (last visited on Mar. 4, 2018).

39 AP, supra note 11. 


\section{B. Modus Operandi}

Overfishing, illegal fishing as well as the depletion of fish at sea near Thai shorelines have forced fishing vessels to go further out to the high seas, reaching remote corners to find new stocks of fish. Consequently, they have to spend longer periods at sea and pay higher logistical costs amid a bitter competition on the global market. ${ }^{40}$ Moreover, due to the nature of fishing which requires workers to spend long period in harsh conditions at sea, the Thai fishing sector has suffered a severe labor shortage, as high as 50,000 workers. ${ }^{41}$ To meet this demand as well as reduce the cost of production, many vessels owners turn to trafficking networks to acquire cheap or even free labor. $^{42}$

Many tragedies of modern-day slavery start with the extreme deprivation of human beings because of poverty, political conflicts, or other difficulties in their countries of origin. Their desire to seek a better life forces them to go somewhere else. What happens in Southeast Asia is not unique. In fact, it follows general pattern of slavery. Human trafficking can be understood as a process which includes four phases: ${ }^{43}$ illicit recruitment, transportation from the place of origin, exploitation (during which the victims are forced into labor or sexual servitude), and laundering the criminal proceeds. ${ }^{44}$ The first three phases describe the process of trafficking itself, while the last process leads us to understand that the crime of trafficking must be seen comprehensively in connection with other separate but connected crimes, such as people and weapons smuggling. For this reason, the UN Protocol to Prevent, Suppress and Punish Trafficking in Persons, Especially Women and Children of 2000 (hereinafter Palermo protocol), ${ }^{45}$ the Smuggling of Migrants protocol, ${ }^{46}$ and the UN Firearms protocol ${ }^{47}$ are supplements to the UN Convention against Transnational

40 S. Robinson, Trafficked: Human Rights Abuses, in SEAFood Industry 12 (2013), available at file://C:/Users/USER/ Downloads/fishwise_human_rights_seafood_white_paper_nov_2013\%20(1).pdf (last visited on Apr. 8, 2018). See also EJF, Slavery at Sea, supra note 10 , at 8-10.

41 UNODC, supra note 6, at 28.

42 Fishwise, supra note 40, at 8-10.

43 UNODC, supra note 6, at 26. See also UNODC, Trafficking in Person: Global Pattern 57 (2006), available at http:// www.un.org/esa/population/migration/turin/Turin_Statements/KANGASPUNTA.pdf (last visited on Apr. 8, 2018).

44 Id.

45 The Protocol to Prevent, Suppress and Punish Trafficking in Persons, Especially Women and Children 2000, available at $\mathrm{https}$ //www.osce.org/odihr/19223?download=true (last visited on Apr. 8, 2018).

46 Protocol against the Smuggling of Migrants by Land, Sea, and Air (2000), available at https://www.unodc.org/ documents/middleeastandnorthafrica/smuggling-migrants/SoM_Protocol_English.pdf (last visited on Apr. 8, 2018).

47 Protocol against the Illicit Manufacturing and Trafficking in Firearms, Their Parts and Components and Ammunition (2000), available at https://treaties.un.org/doc/source/RecentTexts/18-12_c_E.pdf (last visited on Apr. 8, 2018). 
Organized Crime of $2000 .^{48}$

To give flesh and blood to this theory, I will share the story of Mynt Naing, one of the slaves who was freed from Benjina, an island in the Maluku province of Indonesia, known as the Spice Island in Indonesia, after 22 years of slavery. ${ }^{49} \mathrm{He}$ finally returned to his village in Myanmar's Mon State in his middle age, as a stranger or even a 'ghost,' because most the villagers believed he had died a long time ago. The story may end, but his family reminded him that 22 years ago when he was fifteen, his journey to slavery started with a smile and promises of a tall skinny man offering him a hope to have a better life and a good job in Thailand. Mynt was easily convinced. Together with several other young men, he was ready to start a new life with great hope and promise.

After being easily smuggled through the border, Mynt and his fellow Burmese were held for several weeks in a shelter with little food. In response to his confusion, the traffickers told him that he had to wait until everything was arranged. Then suddenly he was pushed by the traffickers to board a boat. He was sold to the sea. ${ }^{50}$ Boat captains are the principal perpetrators in the chain of crime, since most of slaves are received by them to be kept in their boats for labor. By giving the responsibility to recruit workers to captains, business owners could easily limit their own criminal liability. ${ }^{51}$ Mynt worked day and night, almost 24 hours a day, for a salary USD 10 per month or nothing at all. All documents like seafarer books, which were accepted as the entry permit for fishermen in Indonesia, were faked and kept by the captain. ${ }^{52}$

A slightly different pattern of trafficking was shared by Husein, who was trafficked from the Myanmar's Rakhine State, a province where around one million ethnic Rohingyas are experiencing state and communal persecution and extreme deprivation. While Mynt's habitual residence is not too far from the border and the traffickers could easily skirt him by land, Husein had to jump over a crowded boat to reach the border. Most Rohingyas have to pay to smugglers before they can board the boat, although, in some cases, they could jump on it and pay later. Once they reached their destination, the laborers were kept in trafficking camps in southern

48 The United Nation Convention against Transnational Organized Crime 2000.

49 M. Mason, Myanmar fisherman goes home after 22 years as a slave, AP, July 1, 2015, available at http://www.ap.org/ explore/seafood-from-slaves/myanmar-fisherman-goes-home-after-22-years-as-a-slave.html (last visited on Mar. 4, 2018).

$50 \quad I d$, at 59.

51 E. Stoakes et al., Revealed: How the Thai Fishing Industry Trafficks, Imprisons and Enslaves, GuARDIAN, July 20, 2015, available at https:/www.theguardian.com/global-development/2015/jul/20/thai-fishing-industry-implicatedenslavement-deaths-rohingya (last visited on Mar. 4, 2018).

52 IOM, supra note 5 at 7-8. 
Thailand, either in Songkhla or Narathiwat provinces. ${ }^{53}$ Those who already paid their 'transportation cost' could immediately be sold (transferred) again to business sectors like agriculture, construction, and fishing industries in Thailand and Malaysia, with the traffickers normally receiving USD 1,000 per sale from the business owners. Those who were unable to pay were abandoned to die, as indicated by the discovery of mass graves in 2015.

\section{Legal and Conceptual Reflection}

\section{A. Trafficked or Smuggled?}

The nature of modern-day slavery is very difficult to assess because it is hidden behind walls of valid labor contracts or certain cultural practices. ${ }^{54}$ In the context of slavery at sea, the offences have been relatively hidden for decades because of at least three factors: (1) slavery practices happen in complete isolation at sea; (2) fishermen are reluctant to see themselves as victims of human trafficking (most of them see this as part of their job's risks); and (3) government officials do not regard these criminal acts as human trafficking. ${ }^{55}$

If putting slavery at the end of a continuum of hardship in working conditions, how we can draw the line in between mere hardship in labor conditions and slavery? Furthermore, since most cases of human trafficking are transnational involving foreign migrants, how we can draw the line between migrant smuggling and human trafficking? Legally and conceptually, it has been demarcated as specified in two different international conventions: the so-called Palermo protocol and the Smuggling protocols. However, these practices are actually diffuse, fluid, and dynamic and cannot be differentiated easily. ${ }^{56}$ The Palermo protocol defines human trafficking as:

53 Human Right Watch, Mass Graves of Rohingya Found in Trafficking Camp, May 1, 2015, available at https://www. hrw.org/news/2015/05/01/thailand-mass-graves-rohingya-found-trafficking-camp (last visited on Mar. 4, 2018). Southern Thailand especially in 4 provinces (Songkhla, Yala, Narathiwat, and Pattani) are a conflict area in which Barisan Revolusi National - National Liberation Front - of Malay people has demanded independence since the 1950s. This makes the trafficking, smuggling, and conflict situation mix all together. The trafficking camp built in the conflict area indicate that the traffickers can safely operate their offenses.

54 TIP Report 2015, at 20. For details, see R. Plant, What does it mean to be a slave in the 21st century?, GuARDIAN, Apr. 3, 2013, available at https://www.theguardian.com/global-development/poverty-matters/2013/apr/03/slave-21stcentury (last visited on Apr. 8, 2018).

55 UNODC, supra note 6.

56 Chacon, supra note 22, at 2986. 
... the recruitment, transportation, transfer, harboring or receipt of persons, by means of the threat or use of force or other forms of coercion, of abduction, of fraud, of deception, of the abuse of power or of a position of vulnerability or of the giving or receiving of payments or benefits to achieve the consent of a person having control over another person, for the purpose of exploitation. Exploitation shall include, at a minimum, the exploitation of the prostitution of others or other forms of sexual exploitation, forced labor or services, slavery or practices similar to slavery, servitude or the removal of organs... ${ }^{57}$

Such a sophisticated legal definition can be classified into three elements as: action (harboring, transferring, receiving, transportation, and recruitment); means (coercion, abduction, fraud, deceit, deception, abuse of power, abuse of a position of vulnerability, and buying or selling control of a person); and purpose (exploitation of prostitution, sexual exploitation, forced labor, servitude, slavery, practices similar to slavery, slavery-like condition, and removal of organs). ${ }^{58}$

Although this has a close connection with smuggling crimes, normatively the line can be drawn, as smuggling is defined as: “...the procurement, in order to obtain, directly or indirectly, a financial or other material benefits, of the illegal entry of a person into a State Party of which the person is not a national or a permanent resident." 59 Trafficking offenses have two essential 'ingredients,' which are 'exploitation' and 'coercion.' Similarly, smuggling offenses are also composed of two basic elements: illegal border crossing and the receipt of a material benefit by smugglers. ${ }^{60}$

From the above two definitions, we can determine several differences between human trafficking and smuggling: (1) smuggling does not require coercion and deception as a voluntary act, while human trafficking needs compulsion; (2) the role of the smuggler ends once victims reach their destination, while human trafficking can lead to subsequent exploitation; (3) smuggling requires crossing an international border, while human trafficking can happen domestically; ${ }^{61}$ and (4) smuggling necessarily involves illegal entry to a foreign state, while victims of human trafficking can enter a given state both legally and illegally. Just as it is difficult to make a clear distinction between prostitution and sexual exploitation, however, so does the line

57 Palermo Protocol art. 3(a).

58 A. Gallagher, The International Law of Human Trafficking 25-34 (2010). [Emphasis added]

59 Smuggling of Migrants Protocol art. 3(a).

60 J. Bhabha, Trafficking, Smuggling and Human Rights, Migration Information Source, Mar. 1, 2005, available at http:/www.migrationpolicy.org/article/trafficking-smuggling-and-human-rights (last visited on Mar. 4, 2018).

61 ОвокатА, supra note 17, at 20-1. 
blur between trafficking and smuggling, especially in the transnational context. It is easier to identify smuggling offenders than traffickers, since proving the existence of elements like exploitation and coercion requires a deeper and subtler investigation.

This point of view is commonly found among government officials who are responsible for enforcing the law both in Thailand and elsewhere. Before 2008, for example, almost no men have ever been identified as victims of human trafficking. Thai law considered victims of slavery as exclusively women and girls, especially in the sex industry, while men were seen as victims of smuggling. ${ }^{62}$ Only since the enactment of the Anti-Trafficking in Persons Act 2008, labor trafficking has been recognized as a crime in Thailand. ${ }^{63}$ In 2012, for example, law enforcement agencies inspected 54,090 workplaces, and found thousands of indications of human trafficking, but only two cases were recognized as forced labor, for which no one was charged. ${ }^{64}$ In Kantang, where 14 Burmese slaves were freed from a boat in March 2013, the crew master was the only one who charged with an offense, "harboring undocumented migrants," and sentenced to 3.5 months in prison. Any indictment related to forced labor and human trafficking was evaded, and no other persons were charged. The police did not even investigate the boats and pier owner. ${ }^{65}$ All of this occurred because law enforcers in Southeast Asia generally, and in Thailand particularly, have seen human trafficking as identical to sexual exploitation.

To some extent, the proximity of human trafficking with the sexual exploitation and female victims is understandable bearing in mind that four human trafficking laws and treaties in early modern time, were historically enacted to prevent women's trafficking for sexual exploitation. The International Agreement for the Suppression of the White Slave Traffic 1904 was ratified by European countries to prevent the procurement and transportation of white women in Europe for sexual exploitation. 'W6 'White slavery' initially referred to female factories in England, but is now used to describe the slavery of white women for prostitution. The International Convention for the Suppression of the White Slave Traffic 1910 echoed the previous agreement. ${ }^{67}$ However, it emphasized the state responsibility to punish offenders with a harsher sentence and urged to suppress the crime. The International Convention for

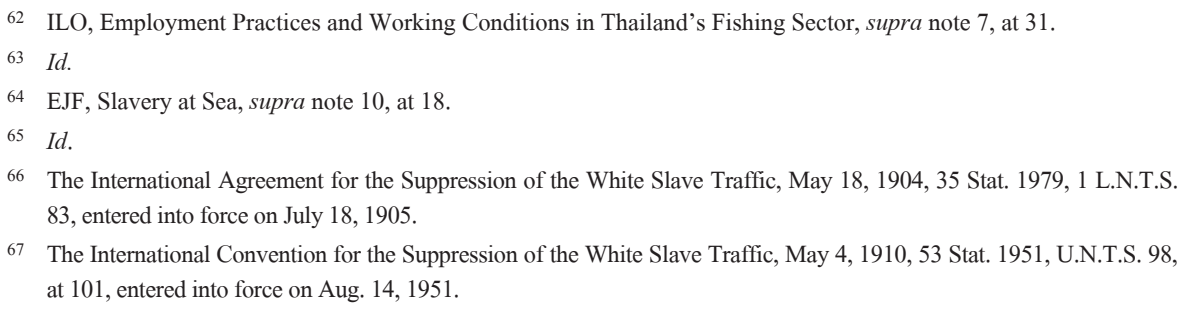


Suppression of the Traffic in Women and Children 1921 was another treaty similar to the previous one, ${ }^{68}$ but it stipulated articles to deal with prostitution and sexual exploitation as important parts of trafficking. ${ }^{69}$ The major difference was that the 1921 Convention does not use the term of 'white slave,' indicating that slavery could happen to any race. The International Convention for the Suppression of the Traffic in Women of Full Age 1933 stipulates the same language and definition as the previous convention, mainly focusing on prostitution and sexual exploitation. ${ }^{70}$

Meanwhile, the Convention for the Suppression of the Traffic in Persons and the Exploitation of the Prostitution of Others 1949 marked the consolidation of all previous treaties. ${ }^{71}$ This Convention recognizes men and boys to be victims of trafficking with gender-neutral provisions. As can be seen in the Palermo protocol, however, the gravity of the law still mainly emphasizes the eradication and prevention of human trafficking of women and girls. This, to a great extent, has given a strong impression to state parties and law enforcers that their main focus is on women trafficking, ignoring the possibility that slavery happens in other sectors and victimizes both women and men. ${ }^{72}$

The UNODC Global Report on Trafficking 2009 describes three reasons why labor trafficking is less visible in comparison to sex trafficking for decades. ${ }^{73}$ First, the problem of legislation, in which for many years forced labor was excluded from trafficking offenses. Second, the general assumption among government officials and the general population that human trafficking is synonymous with sexual exploitation. Third, the visibility bias, in which most labor trafficking is hidden and in isolation (plantation, construction, and fisheries are good examples of how labor slavery is almost entirely hidden). ${ }^{74}$

In addition, the US foreign policy under Bush administration contributed to the situation. From 2001 to 2008, TIP Reports, annually measured the implementation of anti-trafficking laws globally, but they were conflated with prostitution due to the strong lobby of Evangelical Christians, radical feminists, and neo-conservative

68 The International Convention for the Suppression of the Traffic in Women and Children, Sept. 30, 1921. L.N.T.S. 9, at 415 , entered into force on June 15, 1922.

69 Id. $\S \S 6 \& 7$.

70 The International Convention for the Suppression of the Traffic in Women of Full Age, Oct. 11, 1933. L.N.T.S. 150, at 431, entered into force on Aug. 24, 1934.

71 The Convention for the Suppression of the Traffic in Persons and the Exploitation of the Prostitution of Others, Mar. 21, 1950. U.N.T.S. 96, at 271, entered into force July 25, 1951.

72 Shamir, supra note 21, at 88. See also UNODC, Global Report on Trafficking in Persons 51 (2009), available at http://www.unodc.org/documents/human-trafficking/Global_Report_on_TIP.pdf (last visited on Apr. 8, 2018).

73 UNODC, id.

74 Id. 
groups. Only after new staff were installed in the State Department's Trafficking in Persons Office in 2006, TIP Report included labor trafficking and slavery in other sectors like plantation, mining, and the fishing industry. ${ }^{75}$

\section{B. Domestic and Regional Regulations}

The rise of global awareness to combat human trafficking in the last decade could not be separated from two primary legal instruments: The Palermo protocol and the US Victims of Trafficking and Violence Protection Act of 2000 ("TVPA"). ${ }^{76}$ The Palermo protocol has been ratified by 177 parties as of April 2018. ${ }^{77}$ Because of its wide acceptance, the protocol has been binding the international community as a whole like customary international law. Despite its shortcomings, the protocol shows the international community's will to fight against human trafficking as part of transnational organized crime. It also provides comprehensive guidelines on how to combat human trafficking based on the so-called ' $3 \mathrm{P}$ ' approach: Prosecute the perpetrators, Protect the victims, and Prevent the crime from occurring again in the future. [Emphasis added] Importantly, the Palermo protocol provides an agreedupon and broad definition of human trafficking, which was never achieved before the adoption of the protocol in $2000 .^{78}$

TVPA, enacted weeks before the UN General Assembly adopted the Palermo protocol in 2000, is considered the most comprehensive domestic legislation to combat human trafficking in the world. More importantly, the TVPA has had an impact beyond the US border, because it promulgates sanction mechanisms, for example, by withdrawing the US foreign assistance for foreign countries failing to meet the minimum standards for the elimination of trafficking. ${ }^{79}$ The act gives a mandate to the US President to establish the Interagency Task Force to Monitor and Combat Trafficking, chaired by the Secretary of State. This task force is authorized by TVPA to measure and evaluate the progress of combating human trafficking based

75 Shamir, supra note 21, at 92.

76 US Victims of Trafficking and Violence, Protection Act of 2000, H.R. 3234, Pub. L. No. 160-386 § 2A, 114 Stat. 1464 (2000), available at https://www.state.gov/j/tip/laws/61124.htm (last visited on Apr. 8, 2018).

77 See UN Treaty Collection, available at https://treaties.un.org/pages/ViewDetails.aspx?src=TREATY\&mtdsg no=XVIII-12-a\&chapter=18\&clang= en (last visited on Mar. 4, 2018).

78 L. Shoaps, Room for Improvement: Palermo Protocol and the Trafficking Victims Protection Act, 17 LEWIS \& CLARK L. Rev. 934-5 (2013). See also A. Gallagher, The International Law of Human Trafficking 12-3 (2010).

79 J. Chuang, The United States As Global Sheriff: Using Unilateral Sanctions to Combat Human Trafficking, 27 MicH. J. INT'L L. 439 (2005-06). For the minimum standards for the elimination of human trafficking, see TVPA § 108(a) 22 U.S.C. 7106. 
on the '3P' approach, both in the US and globally. ${ }^{80}$

As part of this evaluation, TVPA authorizes the publication TIP annually, ${ }^{81}$ measuring each country's effort to meet the minimum standards set by the Act. Each country is grouped into three different tiers, from 1 to 3 . Tier 1 shows a group of countries that meet the minimum standard, while Tier 3 categorizes countries whose governments neither fully comply with the minimum standard, nor make any significant effort to do so. In between are Tier 2 and the Tier 2 Watch List, listing countries that do not fully comply with the standard but show a significant effort to comply. ${ }^{82}$

Based on these two legal frameworks, we will see briefly how Thailand in particular, and the ASEAN community as a regional organization, make an effort to comply with the minimum standards of combating human trafficking.

\section{Thailand}

After four consecutive years (2010-13) on the Tier 2 Watch List, TIP Report downgraded Thailand to Tier 3 in 2014 and 2015. ${ }^{83}$ This means that: Thailand was in the midst of a serious crisis of human trafficking; did not fully comply with the minimum standards of the TVPA; and made no significant efforts to combat human trafficking that in various sectors from the sex industry to forced labor in its fishing industry. ${ }^{84}$ To ensure fair judgment, let me now review Thai domestic laws regarding human trafficking and the protection of labor, with particular attention to fishing industry.

At least three legal domains are interlinked in the case of human trafficking in fishing industry: regulation of fisheries, labor, and human trafficking. Thailand has relatively comprehensive regulations for these three related sectors. Firstly, the core regulation for the fishing sector is The Fisheries Act, B. E. 2490 of $1947 .^{85}$ This Act regulates the registration and licensing of fishing equipment, permits and the requirement for fishers, as well the type of fishing techniques that are legally allowed.

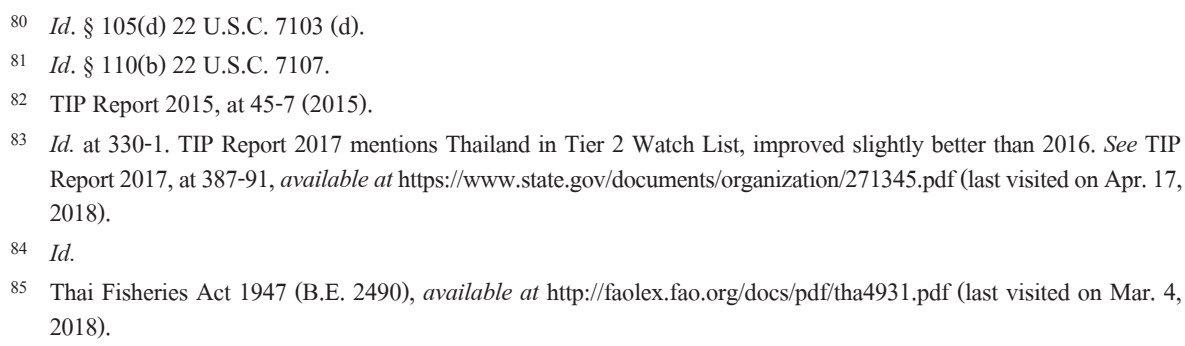

83 Id. at 330-1. TIP Report 2017 mentions Thailand in Tier 2 Watch List, improved slightly better than 2016. See TIP Report 2017, at 387-91, available at https://www.state.gov/documents/organization/271345.pdf (last visited on Apr. 17, 2018). 
Thai officials and other stakeholders like FAO and ILO generally agree that the Fisheries Act is already out of date and must be revised. ${ }^{86}$ It was enacted when the Thailand fisheries were still part of a traditional and artisanal industry, long before Thailand became one of the biggest fish producers in the world. To cope with this rapid development and to meet international pressure, the government prepared a new Fisheries Act in 1999. After long debate and discussion, in 2014, the Draft was submitted to the National Legislation Assembly and passed in 2015. This new Act regulates fisheries in three zones: Inland, Coasts, and High Seas. It aims to tackle the problem of illegal unreported and unregulated fishing ("IUU") which has endangered the sustainability of the fishing industry. ${ }^{87}$ The 2014 Act not only regulates the monitoring and surveillance of fishing activities, but also promulgates the regulations to eliminate all forms of forced labor and improve working conditions both in fishing vessels and seafood processing plants. ${ }^{88}$ However, since the law has only recently been passed, we are currently unable to judge its impact on the improvement of the fishing sector, including its influence on eliminating human trafficking.

Secondly, with regards to labor rights, Thailand has enacted several regulations, including the Labor Protection Act of 1998 and its amendments (2008 and 2010), the Labor Relations Act of 1975, the Act on Establishment of Labor Courts and Labor Court Procedures of 1979, the Social Security Act of 1990, and the Compensation Act of $1994 .^{89}$ All of these regulations deal with common provisions in regulating the relationship between employers and employees, such as minimum wage (300 THB/day nationally), working hours and leave conditions, and termination of employment. Seeing the list of regulations, employees in Thailand are relatively well protected. However, as most of the foreign migrants who work on the fishing vessels and in the seafood factories are recruited illegally, the majority of these workers are unprotected. Most of the contracts between boat owners and the fishers are made without any written documents. Due to the nature of working conditions at sea, most of the employees do not have normal working hours, health insurance, and other benefits promulgated by the law..$^{90}$

Thirdly, following the ratification of the Palermo protocol in 2001, Thailand

86 IOM, supra note 5, at 9-10.

87 Thai Anti-Human Trafficking Action, The New Fisheries Act, Jan. 15, 2015, available at http://www.thaiantihumantraffickingaction.org/Home/?p=457 (last visited on Mar. 4, 2018).

88 Business and Human Rights Resources Center, Highlights of Thailand's new fisheries Legislation, Nov. 26, 2015, available at $\mathrm{https}$ //business-humanrights.org/en/highlights-of-thailands-new-fisheries-legislation (last visited on Mar. 4, 2018).

89 Thai Anti-Human Trafficking Action, supra note 87.

90 IOM, supra note 5 at 9-11. 
enacted the Anti-Trafficking in Persons Act (“ATIP”) in 2008 (B.E 2251). ${ }^{91}$ ATIP mirrors the Palermo protocol. It contains 6 chapters covering general provisions (Chapter 1), the establishment of the Anti-Trafficking Committee (Chapter 2), promulgating powers and duties of officials (Chapter 3 ), the protection and assistance of the victims of trafficking (Chapter 4), establishing a fund to combating trafficking in persons (Chapter 5), and sanction and penalties (Chapter 6). In a more detailed description than the Palermo protocol, Section 6 of ATIP 2008 defines trafficking as:

\begin{abstract}
Whoever, for the purpose of exploitation, does any of the following acts: (1) procuring, buying, selling, vending, bringing from or sending to, detaining or confining, harboring, or receiving any person, by means of the threat or use of force, abduction, fraud, deception, abuse of power, or of the giving money or benefits to achieve the consent of a person having control over another person in allowing the offender to exploit the person under his control; or (2) procuring, buying, selling, vending, bringing from or sending to, detaining or confining, harboring, or receiving a child; is guilty of trafficking in persons. ${ }^{92}$
\end{abstract}

Before the enactment of this trafficking law, Thai law enforcement of trafficking relied mainly on an outdated anti-trafficking law called the Trafficking in Women and Girls Act of 1928, which, reflecting the older anti-trafficking mindset, solely addressed combating the trafficking of women and girl for sexual exploitation. ${ }^{93}$ ATIP, amendment of the 1928 Act, addresses trafficking in various sectors and in gender-neutral terms. It severely penalizes offenders while also advocating the protection of victims. Chapter 6 mentions that the offenders "shall be liable to the punishment of imprisonment from four years to ten years and fine from eight thousand Bath to two hundred thousand Bath." "94 Furthermore, Section 54 lays down that anyone who obstructs the process of investigation, inquiry, prosecution, and proceedings of human trafficking cases shall be liable to a maximum of ten years' imprisonment. ${ }^{95}$ Following the Palermo protocol and TVPA, ATIP 2008 also follows the '3P' (Prosecution, Protection, and Prevention) approach. Chapter 4 regulates the protection and assistance of the victims of human trafficking by providing, for example, food, shelter, medical treatment, psychological and mental rehabilitation,

\footnotetext{
91 Thailand Anti-Trafficking in Persons Act B.E 2551 (2008) [Thailand], 30 January 2008, available at http://www. refworld.org/docid/4a546ab42.html (last visited on Apr. 18, 2018).

92 ATIP 2008, § 6.

93 Овоката, supra note 17 , at 47-8.

94 ATIP 2008, § 52.

95 Id. $\$ 54$.
} 
education, and compensation. It also obliges the authorities to provide safety, especially during the process of legal proceedings, both for the victims and their families. ${ }^{96}$ Similar to the wording used by the Palermo protocol, however, ATIP does not clearly oblige the government to assist the victims, for example, by saying: "The Ministry of Social Development and Human Security shall consider providing assistance as appropriate...,97

In light of the regulations mentioned above, the question of law enforcement becomes crucial for discussion. In most cases, the written law does not represent reality due to the lack of enforcement. We can refer to several reports to judge whether Thailand has sufficiently enforced the law to meet the minimum standards of combating and preventing human trafficking, especially in its fishing industry. TIP Report is the primary source for evaluation. In addition, media reports as well as academic articles are utilized to clarify the Report.

TIP Report indicates that, in the past eight years, Thailand failed to meet the minimum standards to combat human trafficking. ${ }^{98}$ It remains in between the Tier 2 Watch List and Tier 3. Of course, Thailand has made some efforts to curb trafficking, including legalizing undocumented migrants, increasing the frequency of boat inspections, and arresting some perpetrators. However, these efforts were far from enough to meet the minimum standard, and seem to indicate an artificial gesture without a genuine political will. TIP Reports 2014 and 2015 downgraded Thailand to Tier 3 after several years right on the verge. ${ }^{99}$

There are at least three reasons why Thailand has failed to curb human trafficking and improve labor conditions in its fishing industry. ${ }^{100}$ First, the Thai government did not have real political will. Despite the fact that the government has assigned high officers to tackle those problems as: improving inspection mechanisms for vessels; assimilating undocumented foreign migrants; and prosecuting trafficking cases, a real impact on improving conditions is still unseen. TIP Report highlights the tendency of symbolic gestures of the government without real concrete action, by stating: "senior officials regularly made public statements expressing their commitment to combating

96 Id. $\$ 36$.

97 Id. § 33. [Emphasis added]

98 TIP Report 2015, at 330-1.

99 Id. For details on a complete report, see EJF, Slavery at Sea, supra note 10.

100 Id. at 30-2. For details on the corruption and human trafficking in Thailand, see M. Sakdiyakorn \& S. Vichitrananda, Corruption, Human Trafficking and Human Rights: The Case of Forced Labor and Sexual Exploitation in Thailand, NACC J. 54 (July 2010), available at https://www.nacc.go.th/images/journal/malinvisa.pdf (last visited on Mar. 4, 2018). 
trafficking, though these efforts did not always yield concrete results." ${ }^{\text {"101 }}$ In addition, the lack of competent interpreters in assisting victims either during the investigation process or court hearings indicates inadequacy of the system to tackle trafficking. ${ }^{102}$

Second, endemic corruption has seriously hindered law enforcement in curbing modern-day slavery in Thailand. ${ }^{103}$ Furthermore, in many ways, corruption helps facilitate the mushrooming of human trafficking. Several TIP Reports from 2012 continuously urged the Thai government to tackle this issue seriously, because corruption is rampant at every stage of human trafficking, from recruitment to transportation and exploitation by employers. Thai immigration officers, police, and military have been involved in this illicit misuse of entrusted power for their own personal gain. The 2014 TIP Report states: "Thai civilian and military officials profited from the smuggling of Rohingya asylum seekers from Burma and Bangladesh ... and were complicit in their sale into forced labor on fishing vessels." ${ }^{104}$ Thai navy and marine officials also allegedly towed boats loaded by migrants from Myanmar to Thai coastal area and sold them to brokers, who then re-sold the victims to the fishing boats. ${ }^{105}$ Thai police systematically removed Rohingyas from the detention facilities and transported them to Southern Thailand. The middlemen brokered the selling of the victims to traffickers as labor, either in jungle camps as cooks and guards, or on the fishing boats. ${ }^{106}$

In fact, corruption is not a problem unique to Thailand. It happens everywhere, oiling the wheels of human trafficking around the world. Using statistical correlation tests between human trafficking and other factors like poverty, education, and corruption, Zhang and Pineda have shown that corruption is the only consistent causal factor for human trafficking. ${ }^{107}$ They utilized TIP Reports (Tier 1 to 3 ) as the variable for human trafficking, and the Corruption Perception Index (CPI index) of Transparency International to measure corruption (1 to 10 index in which 1 shows

101 TIP Report 2013, available at http://www.state.gov/j/tip/rls/tiprpt/countries/2013/215633.htm_(last visited on Mar. 4, 2018).

102 EJF, Slavery at Sea, supra note 10, at 21-2.

${ }^{103}$ K. Hodal, Slavery and Trafficking Continue in Thai Fishing Industry, Claim Activists, Guardian, Feb. 24, 2016, available at https://www.theguardian.com/global-development/2016/feb/25/slavery-trafficking-thai-fishing-industryenvironmental-justice-foundation_(last visited on Mar. 4, 2018). See also EJF, Slavery at Sea, supra note 10, at 24-5.

104 TIP Report 2014, available at http://www.state.gov/j/tip/rls/tiprpt/countries/2014/226832.htm (last visited on Mar. 4, 2018).

105 Id.

106 Id.

107 S. Zhang \& S. Pineda, Corruption as a Casual Factor in Human Trafficking in Organised Crime: Culture Market AND Policies 41-53 (D. Siegel \& H. Nelen eds., 2008). 
the least corrupt while 10 the worst). ${ }^{108}$ They also evaluated the correlation between trafficking and poverty levels, using several variables like income per capita, mortality rate, education, and life expectancy. ${ }^{109}$ According to this research, 'poverty' is inconsistent with trafficking, considering that many countries on TIP Report's Tier 2 Watch List and Tier 3 are not poor countries. The only consistent variable correlated to trafficking is 'corruption.' The more corrupt a country is, the higher its human trafficking rates are. ${ }^{110}$

Lastly, concerning trafficking in fishing industry, the reluctance of business owners to modernize their industry is a crucial factor influencing continued trafficking. After a wave of trawl modernization in the 1960s supported by the West German government, Thai fishing industry grew rapidly. Its marine capture increased dramatically from 63,711 tons in 1960 to 2 million tons in the 1980s. ${ }^{111}$ Because of unregulated practices and excessive captures, however, production started to decline, which has forced boat owners to sail far away from the Gulf of Thailand to Indonesian, African, and even Russian waters. Unfortunately, after more than two decades, fleet rejuvenation by more technologically-advanced equipment is not on their agenda. To meet the minimum catch, business owners rely mainly on labor forces easily recruited through trafficking networks and organized crime. ${ }^{112}$

\section{ASEAN}

Since the problem of human trafficking is not unique to Thailand, it is important to touch briefly upon regional legal instruments and guidelines on human trafficking. There is no particular regional instrument in dealing with trafficking in fishing industry; it is rather considered as part of trafficking in general. In this regards, the Bali Process on People Smuggling, Trafficking in Persons and related Transnational Crime (hereinafter Bali Process) is considered a comprehensive regional instrument dealing with this issue. With around 48 members, the Bali Process has effectively raised the awareness of human trafficking problems in a wider region, from Vanuatu to Iran. Because it deserves a separate deep discussion, however, this paper will focus instead on the Association of the Southeast Asian Nations. ("ASEAN") 113

\footnotetext{
108 Id.

109 Id.

110 Id. See also K. Bales, Understanding Global Slavery: A Reader 15-6 (2005); K. Richards, The Trafficking of Migrant Workers: What are the Links between Labor Trafficking and Corruption? 42 InT'L Migration 5 (2004).

111 EJF, Slavery at Sea, supra note 10, at 6-8.

112 Id. See also EJF, Slavery at Sea, supra note 10, at 32.

113 S. Kneebone, The Bali Process and Global Refugee Policy in the Asia-Pacific Region, 27 J. Refugee Stud. 596 (2014).
} 
Since the 1990s, the ASEAN member states have recognized the threat of human trafficking, especially concerning women and girls as victims. ${ }^{114}$ In 1997, three years before the Palermo protocol was ratified, the ASEAN member states signed the ASEAN Declaration on Transnational Crime, whose main concern was to confront transnational crimes "such as terrorism, illicit drug trafficking, arms smuggling, money laundering, traffic in person and piracy." encouraged its members to enhance regional cooperation through both bilateral and multilateral channels in combating transnational crimes, including human trafficking. In 2004, following the Palermo protocol, the ASEAN countries ratified the ASEAN Declaration against Trafficking in Persons Particularly Women and Children. ${ }^{116}$ Until 2015, this Declaration was recognized as the main legal instrument, although nonbinding, for member states to cooperate in combating human trafficking. Because almost all the ASEAN legal instruments rely on a 'soft-law' approach, ${ }^{117}$ these instruments and guidelines are not fully effective in eliminating trafficking. In short, Kranrattanasuit said: "These instruments are unequal in their approaches at gender sensitivity, contain ambiguous and insufficient anti-human trafficking content, lack trafficking victims protection, and exhibit no common anti-human trafficking norms." 118 In spite of creating the ASEAN Inter-Governmental Commission on Human Rights ("AICHR"), it has not established a monitoring and evaluation mechanism in combating trafficking yet. This renders both the instrument and the AICHR toothless. The 2004 Declaration was merely advice and encouragement for member states to establish domestic mechanisms to combat human trafficking, without a comprehensive regional approach. ${ }^{119}$

In the wake of a shameful and grave humanitarian crisis in November 2015,

See also A. Klug, Enhancing Refugee Protection in the Asia-Pacific Region, 107 Am. Soc'y Int'L L. Proc. 358 (2013).

114 See ASEAN Response to Trafficking in Person 3 (2006), available at http://203.149.11.174/ewt_dl_link. php?nid=1312 (last visited on Apr. 8, 2018).

115 See ASEAN Declaration on Transnational Crime 1997, available at http://asean.org/?static_post=asean-declaration-ontransnational-crime-manila-20-december-1997 (last visited on Apr. 8, 2018).

116 See ASEAN Declaration against Trafficking in Person Particularly Women and Children 2004, available at http:// asean.org/asean-declaration-against-trafficking-in-persons-particularly-women-and-children-4 (last visited on Mar. 4, 2018).

117 In contrast to the 'hard law' approach, 'soft law' is generally regarded as "head without a body" mechanism without binding force. See Kranrattanasuit, supra note 18, at 55. See also, e.g., A. D'Amato, Softness in International Law: A Self-Serving Quest for New Legal Materials: A Reply to Jean d'Aspremont, 20 EuR. J. INT'L L. 897 (2009), available at http://www.ejil.org/pdfs/19/5/1700.pdf (last visited on Apr. 4, 2018).

118 Kranrattanasuit, supra note 18, at 52.

119 For details on the deficiency of the ASEAN Instruments on Human Trafficking, see id. at 52-72. However, Kranrattanasuit's book was published before 2015 when the ASEAN was agreed on a new convention on human trafficking. 
thousands of refugees and migrants from Myanmar flooded neighboring countries such like Thailand, Malaysia, and Indonesia. Then, the ASEAN member states took a bold step by creating a historic ASEAN Convention and Plan of Action against Trafficking in Persons Especially in Women and Children ("ACTIP"). ${ }^{120}$ After finding the mass grave of Rohingyas in the trafficking jungle camp in Thailand and wide media coverage of slavery in various sectors, mainly fishing industry, the leaders of the member states finally realized that they would not be able to combat trafficking individually, but collective action was needed. As opposed to the 2004 Declaration, which was non-binding, ACTIP is a binding mechanism as a guideline for a regional effort to combat human trafficking. ${ }^{121}$ Following the Palermo protocol's '3P' approach, ACTIP aims to combat and punish effectively traffickers, protect and assist the victims with full respect for their human rights, and promote cooperation among the ASEAN member states to meet these objectives. ${ }^{122}$ Article 24 of ACTIP stipulates a monitoring, reviewing, and reporting mechanism, authorized by the ASEAN Senior Officials Meeting on Transnational Crime ("SOMTC"). ${ }^{123}$

Nonetheless, there is a barrier to action: ACTIP and the Plan of Action would be only eligible for implementation 30 days after being ratified by at least six member countries. ${ }^{124}$ In 2016, only three states, Singapore, Cambodia and Thailand, ratified the Convention. ${ }^{125}$ By March 2017, the ASEAN announced that ACTIP should be official after the final ratification of Vietnam, Myanmar and the Philippines. ${ }^{126}$ This development promises a better pathway into combating human trafficking in the region. For the time being, however, we have to wait and see if member states implement this new legislation in real policy and action.

\footnotetext{
120 ASEAN Convention and Plan of Action against Trafficking in Persons Especially in Women and Children 2015 (ACTIP), available at http://www.asean.org/wp-content/uploads/2015/12/ACTIP.pdf (last visited on Mar. 4, 2018).

121 Id.

122 Id. arts. 23-24.

123 Id.

124 Id. art. 29.

125 L. McCallum, One Year Later: ASEAN Anti-Trafficking Action Plan Still Dormant, Human Trafficking Center, Sept. 16, 2016, available at http:/humantraffickingcenter.org/one-year-later-asean-anti-trafficking-action-plan-still-dormant (last visited on Mar. 4, 2018).

126 ASEAN Secretariat, ASEAN Welcomes Entry into Force of ACTIP, Mar. 8, 2017, available at http://asean.org/aseanwelcomes-entry-into-force-of-actip (last visited on Mar. 5, 2018).
} 


\section{Conclusion}

Modern slavery at sea was unseen and ignored for decades because it was isolated and uncontrolled. Due to the conflation of human trafficking with the sex industry and women victims, trafficked persons in other sectors like fishing industry have not been easily regarded as victims of slavery. This has also caused a lack of awareness among state officials regarding slavery in many other sectors out of sex industry, where women and men are equally vulnerable.

My paper has discussed the horrific conditions of slavery at sea with special references to human trafficking cases in Thai fishing industry. The victims of trafficking who are recruited by deception, fraud, and violence could spend months and years at sea in brutal conditions without any opportunity to escape. This type of trafficking is reminiscent of pre-modern slavery, an inhumane practice that we thought disappeared hundreds of years ago.

Combating human trafficking does not simply mean enacting regulation and signing international conventions. Rather, law enforcement, eradication of corruption, socialization, awareness of the crime among state officials, as well as, importantly, political will should be intermingled supporting each other in combating human trafficking. 
